\title{
Efforts to Improve Socio-Economic Society Through the Samisake Program in the Covid-19 Era in Bengkulu City
}

\author{
Achmad Aminudin ${ }^{1, *}$
}

\author{
${ }^{1}$ University of Bengkulu \\ *Corresponding author. Email: achmadaminudinunib@gmail.com
}

\begin{abstract}
The purpose of this research is to find out the efforts of the Bengkulu City Government in improving socio-economic society through the Samisake program in the covid-19 era. Using a four-stage Interactive analysis model (Miles \&amp; Huberman, 1992:20), namely: data collection, data reduction, data presentation, and withdrawal conclusions, the authors can draw the following conclusions; The intervention of the Samamisake revolving fund program has produced program output by reaching program beneficiaries as many as 10253 people consisting of female target groups of $60.68 \%$ and male target groups of $39.32 \%$. Within the past four years the allocation of this revolving fund has grown by $203 \%$ to Rp. 27,822,800,000 from the initial realization of Rp. 13,649,000,000. In the sub-impact of the creation of work fields, the achievement of the program's impact on employment was only $10.49 \%$ or as many as 1,311 workers, from the initial number in 2014 of 11,542 workers to 12,854 workers. As for aspects of business development in the city of Bengkulu as many as 9,279 business people and gave rise to new businesses to 965 people. The achievement of the program's impact is still far from the expected policy target in Perda No. 12 of 2013 which requires the creation of 50,000 jobs for the community in the city of Bengkulu. Second, Efforts to improve socioeconomic society in achieving the program goals are still far from the policy targets expected in Perda No. 12 of 2013 which requires the creation of 50,000 jobs for the people in Bengkulu City. It is expected that the Bengkulu City government needs to reorganize the institutional program in the form of improving the support capacity of regulations and improving program resources while addressing the challenges and obstacles arises in the field.
\end{abstract}

\section{Keywords: Improving, Socio-Economic Society, Samisake Program}

\section{INTRODUCTION}

The implementation of a health emergency in preventing the spread of Coronavirus-19 Disease (COVID) by the Bengkulu City Government by selfisolating at home, working from home, maintaining physical and social distance and regional quarantine has stopped the economic conditions of the community's household, which impact most felt by the lower class of society, including the Micro Credit Institution (Lembaga Kredit Mikro). This condition, according to Minister of Finance Sri Mulyani, causes MSMEs to be unable to carry out business activities so that their ability to fulfill credit obligations is impaired. The government of Bengkulu City has long implemented an unemployment and poverty reduction program through the Urban Independent Community Empowerment Program (PNPM) which later switched management to the One Billion One Village Program (SAMISAKE). The Samisake program as a pro-poor program responds to the poverty problems of Bengkulu City of $\pm 63,000$ people and unemployment of $\pm 70,000$ people (Bengkulu People, December 1, 2014). In 2016, the institutional Samisake revolving fund program underwent a modification from UPTD to BLUD with the issuance of Bengkulu Mayor Regulation Number 51 of 2016 and Bengkulu Mayor Regulation Number 52. The results of the program redesign have directed the program for economic development efforts by building financial institutions at the village level.

This research tries to reveal how the Bengkulu City Government's efforts in improving the community's socio-economy through the Samisake program in the Covid-19 era. One of the efforts to empower and develop the local economy and productive economy is through the provision of revolving fund loans. The Bengkulu City Government in the Bengkulu City Medium-Term Development Plan (RPJMD) 2013-2018 has made the Samisake Revolving Fund loan a regional 
flagship program in the field of poverty alleviation and job creation.

The Samisake Program was formed based on Regional Regulation No. 12/2013 concerning the Management of the Bengkulu City Samisake Revolving Fund, which stipulates in the regional regulation that the management of the Samisake revolving fund is carried out by the UPTD in the relevant Office. The UPTD has the status of a Regional Public Service Agency and in the management of the Samisake revolving fund works closely with Micro Finance Institutions (MFI) in each village.

Then related to the realization of the regional regulation, it is regulated in the Guidelines for the Management of the Samisake Revolving Fund and Regulation Number 28 of 2013 concerning Technical Guidelines for the Management of the Samisake Revolving Fund. As for the vision of the Samisake City of Bengkulu, namely; "Realizing the Welfare of the People of Bengkulu City through Increasing Social Justice incomes".

Statistically, as of March 31, 2014, the Samisake revolving fund had been distributed to 6,508 loan recipients in 56 urban villages. The recipients of these loans consisted of 41 percent men and 59 percent women. This means that more than half of the recipients of the Samisake revolving fund loan are women and are dominated by housewives who try to increase family economic income. During the first quarter of 2014, the Samisake revolving fund was able to create 7,749 new workers. Loans vary from IDR 500,000 to IDR $10,000,000$ with a maximum loan term of 24 months.

\section{RESEARCH PROBLEMS}

Based on the background above, the authors identify two problem formulations, namely: What outputs are delivered / delivered through the Samisake revolving fund program in Bengkulu City? How are the efforts of the Bengkulu City Government in improving the socio-economy of the community through the Samisake program in the covid-19 era?

\section{LITERATURE REVIEW}

Several previous studies in the perspective of the Samisake Revolving Fund Program have been carried out by several previous researchers, namely; Sukatno (2013) examines the Implementation of One Billion One Village (SAMISAKE) Program Policy in Bengkulu City by taking a case study in Padang Jati Village, Ratu Agung District, Bengkulu City. Adityo P. Ramadhan et al, (2014) examined the comparison of the Bengkulu City Poverty Alleviation Program, Micro Credit versus Control of Street Vendors (PKL). Jatmiko Yogopriyatno (2015) reviewed the evaluation of the implementation of the Samisake Revolving Fund Program in Bengkulu City. Achmad Aminudin et al
(2017) examined the sustainability of the Samisake revolving fund program in Bengkulu City.

These studies tend to look at the implementation of the Samisake revolving fund program, report various successes as well as unsuccessful programs. Realizing this condition, in perspective this research is intended to see the impact of the Samisake revolving fund program in Bengkulu City with various issues and problems that have been identified in previous research. The study on the impact of the Samisake revolving fund program in Bengkulu City is seen from two perspectives, namely; 1) Identifying the outputs delivered / given through the Samisake revolving fund program in Bengkulu City; 2) Assessing the impact of the Samisake revolving fund program in improving the socio-economy of the people in Bengkulu City. In addition, research is expected to have value on the development of public policy implementation studies in Bengkulu City related to the impact study of the Samisake revolving fund program.

\section{RESEARCH METHODS}

This research was conducted in a descriptive qualitative way, following the opinion of Moleong (2001: 3), that qualitative methods are easier to adjust when faced with multiple realities, and are more sensitive to the sharpening effect of the value patterns faced. While the analysis used is descriptive analytical and prescriptive synthetic. Analytical descriptive means that the disclosure or description of a factual and accurate situation about the object being observed which is discussed analytically, starts from the thoughts, conceptions, paradigms or theories that underlie or are related to related research. Prescriptive synthesis is intended to rebuild the results of critical analysis that has been carried out so that the relevant and important factors required can be synthesized into a systematic concept. Based on the data obtained, a study will be conducted on the impact evaluation of the Samisake revolving fund program in Bengkulu City.

This research is focused on examining comprehensively the evaluation of the impact of the Samisake revolving fund program in Bengkulu City, as described in the background that in the preparation of the Samisake revolving fund program it is seen from the output and impact of the program. The research aspects studied include:

a. Identifying the output of the Samisake revolving fund program, in terms of the number of target groups as beneficiaries of the program, and the amount of business capital provided.

b. identify the outcome after the project output is known, in terms of individual and group business types after the Samisake revolving fund program which includes: business profile, income from business results, development trends.

c. identify the consequences / impact achievement of the samisake revolving fund program seen from the 
number of workers produced and the type of business generated.

The determination of informants in this approach is more of a "purposive sampling", in which researchers tend to choose informants who are considered to know and are trusted to be accurate data sources and know the problem in depth. Sugiyono (2001: 62) states that purposive sampling is a technique of determining samples for specific purposes only. Where the samples chosen are people who are experts in their fields only. The identification related to informants in this study are as follows:

1. Implementing level bureaucrats, consisting of: technical UPTD staff of the samisake revolving fund, MFI, and Program Facilitators.

2. Beneficiaries (members of the community who are the targets of the Samisake Revolving Fund Program.

\section{DISCUSSION}

The discussion produced in the research on the impact of the samisake revolving fund program developed by the Bengkulu City Government is focused on the number of workers created and the diversion of business resulting from the intervention of the samisake revolving fund program during the four years of the program. The results of research on the output aspect of the program, it is known that the intervention of the samisake revolving fund program has reached 10253 program beneficiaries who are spread across nine districts in Bengkulu City. The proportion of the overall program target group was dominated by the female target group, namely $60.68 \%$, while the male target group was $39.32 \%$.

Then related to the amount of funds realized, at the beginning of the program it was implemented, the samisake revolving fund was realized with a total budget of Rp. 13,649,000,000. In the past four years, this revolving fund allocation has grown by $203 \%$ to Rp $27,822,800,000$. As has been explained in the research results that at the sub-district level, Ratu Samban SubDistrict occupies the top position with the total development of a revolving fund of IDR 4,972,500,000. Meanwhile, the lowest development of revolving funds, namely Rp. 1,350,500,000, was found in Kampung Melayu Sub-District.

Furthermore, when viewed from the MFI/Koperasi level as the manager of the samisake revolving fund in the city of Bengkulu, the Rinjani Maju Women Koperasi with Jembatan Kecil Village is an MFI with excellent performance in the development of the Samisake revolving fund and the highest among 62 MFIs that distribute the Samisake revolving fund.

The Samisake revolving fund that has been distributed by Kopwan is Rp. Rp. 2,221,500,000, - has grown to Rp. $1,921,500,000$, - or 641 percent of the funds transferred from the regional treasury to the MFI's account amounting to Rp. 300,000,000, -. This illustrates the seriousness of the Renjani Maju Bersama Women's Koperasi in managing the Samisake revolving fund which has the aim of improving the economy of the people in Bengkulu City which is the big goal of the Bengkulu City Government of Bengkulu City to reduce poverty and unemployment and create new job opportunities in the Bengkulu City. As for comprehensively related to the 10 best MFIs related to the performance of the samisake revolving fund management in Bengkulu City.

The spread of the corona virus (covid-19) is still a hot issue in the Indonesian world, including in Bengkulu. The World Health Organization (WHO) on Wednesday $(11 / 3)$ officially declared the corona outbreak a global pandemic. This is based on the fast and massive spread of this virus to a number of countries. In less than three months, there have been 118 thousand cases in 114 countries, including Indonesia. In this country, the number of citizens who have tested positive for the corona virus continues to increase. Of course this has an impact on mobilization and productivity, both for professionals and the general public.

The efforts of the Bengkulu City Government in increasing the socio-economic status of the community through the Samisake program in the Covid-19 era experienced obstacles at almost all program and institutional levels. Currently, it can be said that the samisake program is experiencing stagnation in activities. The Bengkulu City Government on the one hand limits community activities by imposing social restrictions, but must also ensure the survival of the community. Availability of basic commodities and the needs of many people. The government's challenges are getting tougher. Change occurs in various aspects of life. Like it or not, there must be changes as well as adapt to the times in order to survive. The world is in shock with the emergence of the Corona Virus Disease (Covid-19) Pandemic, which has had a significant impact on change. Starting from the economic, social, to daily life aspects, almost nothing can escape the emergence of the Covid-19 virus, including public services since the corona virus first appeared in late December 2019.

Since the announcement of a positive case of the Covid-19 virus on March 2, 2020, the Bengkulu City Government has stepped up steps in dealing with the pandemic from Covid-19. Prior to that, the Bengkulu City Government had also increased the preparedness of many hospitals and equipment in accordance with international standards, including the budget specifically allocated for all prevention and treatment efforts.

Since early March 2020, various policies have been issued by the Bengkulu City Government. 
Starting from limiting social relations (social distancing), calling for work from home for most of the State Civil Service (ASN), eliminating worship activities, and asking people to stay at home and reducing economic activities outside the home. This policy has good intentions, but the impact of this policy has high risks, until the end of March 2020 the Bengkulu City Government policy is not only social distancing but continues with Physical Distancing. With so many public service providers limiting services, initiating on-line services and even eliminating temporary services, is a phenomenon that must be done. This limitation of public services has been implemented by the Bengkulu City Government since mid-March 2020, starting with dismissing school children by asking to study at home and then appealing to employees to do Work From Home (WFH).

The implementation of WFH does not apply to all public service providers, because there are several fields that cannot carry out WFH, such as the Department of Population and Civil Registration related to recording $\mathrm{El} \mathrm{KTP}$, regarding motor vehicle tax payments and extension of STNK in Samsat, and fields others who require direct community arrival. Even though it does not apply WFH, it still imposes restrictions on public services. Restrictions are made, such as reducing the number of queues that enter the room and inside the room, and services must follow the recommended safe distance of at least 1 meter.

With the enactment of WFH for employees engaged in public services, causing public services to be hampered, because in the end some sectors of service cannot directly serve the community. However, public service providers then make innovations in providing services so that services are not hampered, such as providing services through an online system. This online system is being promoted by several public service providers to the public so that public services continue to run, for example, some providers who provide services using an online system, namely PLN, which use an online system in providing services ranging from new connections, power changes to complaints in payments via ATM or internet banking. Then the DGT (Directorate General of Taxes) also stopped reporting directly and directed it online and extended the tax reporting period which should have ended on March 31, 2020 to April 30, 2020.

\section{CONCLUSION}

Based on the results of research on the efforts of the Bengkulu City Government in the Covid-19 era in improving the socio-economic community through the Samisake program, it can be concluded as follows:
1. The intervention of the Samisake revolving fund program has produced program output by reaching 10253 program beneficiaries, consisting of $60.68 \%$ of the female target group and $39.32 \%$ of the male target group.

2. Within the last four years, this revolving fund allocation has grown by $203 \%$ to Rp. $27,822,800,000$ from the initial realization of Rp. 13,649,000,000.

3. In the aspect of creating a fun field, the achievement of the impact of the program on employment was only $10.49 \%$ or 1,311 workers, from the initial number in 2014 of 11,542 workers to 12,854 workers. As for the aspect of business development in Bengkulu City, it has contributed to 9,279 more developed entrepreneurs and has created 965 new businesses.

4. The achievement of program objectives is still far from the expected policy targets in accordance with the objectives of Perda No. $12 / 2013$, which requires the creation of 50,000 jobs for the people in Bengkulu City.

5. By looking at the empirical reality in the field, it shows that the achievement of the program objectives of the Bengkulu City Government is still far from the expected policy target in accordance with the objectives of Perda No.12 of 2013 which requires the creation of 50,000 jobs for the people of Bengkulu City. So the Bengkulu City Government of Bengkulu City needs to restructure the program institution in the form of improving the regulatory support capacity and improving program resources as well as responding to the challenges and obstacles that arise from the program implementation process in the field.

6. In addition, it is necessary to carry out further research on the study of implementation efforts, program evaluation and program institutionalization as well as the overall impact of the program as part of future program improvement steps.

\section{REFERENCES}

Burdge, B. \& Vanclay, F. 1996. Social Impact Assesssment: A Contribution to the State of the Art Series. Impact Assessment 14: 59-86

Charles O. Jones dan David Carr Baird, 1991. Pengantar kebijakan publik (public policy), Rajawali. Yogyakarta

Dunn, William N.1998, Pengantar Analisis Kebijakan Publik, Gadjah Mada University Press, Yogyakarta.

Finsterbusch, Kurt and Annabelle Bender Motz 1980. Sosial Research for Policy Decisions, Belmont, California: Wadsworth Publishing Company. 
International Association for Impact Assessment. 2003. Social Impact Assessment - International Principles. IAIA Special Publications Series No.2. Fargo, US

Islami, Irfan, 2002. Prinsip-prinsip Perumusan Kebijakan Negara, Bumi Aksara, Jakarta

Milles M.B., dan A.M. Huberman. 1992. Analisa Data Kualitatif. Universitas Indonesia Pers, Jakarta.

Moleong, Lexy J. 2001. Metodologi Penelitian Kualitatif. PT Remaja Rosda Karya, Bandung.

Peraturan Daerah Kota Bengkulu Nomor 12 Tahun 2013 Tentang Petunjuk Teknis Pengelolaan Dana Bergulir Samisake.

Peraturan Daerah Kota Bengkulu Nomor 27 Tahun 2013 Tentang Petunjuk pelaksanaan Pengelolaan Dana Bergulir Samisake.

Peraturan Daerah Kota Bengkulu Nomor 28 Tahun 2013 Tentang Petunjuk Teknis Pengelolaan Dana Bergulir Samisake.

Sugiyono. 2001. Metode Penelitian Administrasi, Alfabeta, Bandung.

Wibawa, Samodra, dkk. 1994. Evaluasi Kebijakan publik. PT. Raja Grafindo Persada, Jakarta

\section{Website:}

http://www.bengkulu.tv.co.id/ http://www.bengkuluekspress.com/ http://www.bengkulukota.go.id/ 